\title{
Epidemiology and diagnosis of the pancreatic cancer
}

\author{
M. Hidalgo Pascual, E. Ferrero Herrero, M. J. Castillo Fé. F. J. Guadarrama González, P. Peláez Torres and \\ F. Botella Ballesteros
}

Department of General and Gastrointestinal Surgery “B”. University Hospital 12 de Octubre. Madrid. Spain

Hidalgo Pascual M, Ferrero Herrero E, Castillo Fé MJ, Guadarrama González FJ, Peláez Torres $P$, Botella Ballesteros F. Epidemiology and diagnosis of the pancreatic cancer. Rev Esp Enferm Dig 2004; 96: 714-722.

\section{INTRODUCTION}

Pancreatic cancer is the fourth leading cause of cancer-related mortality in the United States. The yearly number of newly-diagnosed patients and the yearly mortality rate are very close together. In 1988, around 27,000 new patients were detected in the United States, and nearly 24,500 of these died; in 1999, 185,000 new cases were recorded, with a death rate of $0.99 ; 28,000$ patients died of this disease in the USA in 1998, which represents a fair estimate of pancreatic cancer yearly increase. In Spain, figures suggest that mortality increased by $164 \%$ in women and by $200 \%$ in males over the past 40 years. More specifically, 58 new cases of pancreatic cancer are diagnosed in our hospital reference area per year ( $8.3 \%$ of all gastrointestinal tumors). The frequency of this disease is only surpassed by that of lung, colorectal, prostate, and breast cancer (1-4).

\section{EPIDEMIOLOGICAL CONSIDERATIONS}

\section{Incidence}

Mortality may be a good frequency indicator, since most patients with pancreatic cancer eventually die of the disease, and diagnosis accuracy is high. Reliability may be checked

Recibido: 24-11-03.

Aceptado: 24-11-03.

Correspondencia: Manuel Hidalgo Pascual. Servicio de Cirugía General y Digestiva "B" (5 planta). Hospital Universitario 12 de Octubre. Ctra. de Andalucía, km. 5,400. 28041 Madrid. Fax: 913908 062. e-mail: mhidalgo.hdoc@salud.madrid.org. by comparing the number of histologically confirmed cases as a result of surgery, biopsy or autopsy to the number of diagnoses. This estimate ranges from 75 to $95 \%$.

\section{Age and gender}

Pancreatic cancer is an increasingly common condition with a diagnosis-death ratio that rises with age. Mean age at presentation is 69.2 years in males and 69.5 years in females according to U.S. National Reports from 1973 to 1977. The male-female ratio varies with age, as reported by a number of authors. Cancer-related deaths range from $2: 1$ in patients younger than 40 years of age to $1: 1$ in patients older than 80 years of age. Current data suggest that male-female ratios by age group are as follows - 3:1 in patients younger than 40 years; $1.8: 1$ from age 41 to age $50 ; 1.2: 1$ between 51 and 80 years of age; and 1.1:1 in patients older than 80 years.

\section{Demographic aspects}

The impact of birthplace has been examined in Israel, and pancreatic cancer incidence ranges from 10.4 per 100,000 among males born in Europe or America to 5.6 per 100,000 among males born in Israel.

Incidence in females shows similar fluctuations in selected regions within a number of countries. For instance, in Canada frequency varies between 11 per 100,000 in Ontario and 3.7 per 100,000 in the Northwest territories. From 1911 to 1971 mortality from pancreatic cancer increased at least five-fold both for men and women in England and Wales.

The frequency of pancreatic cancer varies among different communities or ethnic groups: incidence is 11.7 per 100,000 among Hispanics in Los Angeles, CA, USA, versus 2.0 per 100,000 among the Chinese in this same city. Figures are similarly remarkable in Europe: the yearly rate in France is 6 new cases per 100,000 males and 3 cases per 100,000 females, whereas in Italy is 10 new cases per 100,000 inhabitants. Incidence in Spain is around 7/100,000. 


\section{ETIOLOGY}

A number of environmental factors have been associated with a high risk for pancreatic cancer, but its origin remains unclear. As with other common malignancies, pancreatic cancer seems to be more frequent among individuals in lower socioeconomic groups (5).

\section{Dietary habits}

A number of dietary factors are also involved (6). At least one study demonstrated an actual correlation between coffee ingestion and pancreatic cancer. In this study (7) patients with pancreatic cancer were found to have a stronger history of coffee ingestion when compared to a control group made up of patients with benign gastrointestinal disturbances. At least two additional studies have been carried out, which have not confirmed such association of coffee ingestion with pancreatic cancer (8).

Howe and Burch (9), in their conclusions on a multicenter study to assess micronutrients and pancreatic cancer, reported an increased risk in association with carbohydrate and cholesterol ingestion concurrently with a decreased consumption of fiber and vitamin C.

\section{Alcohol and tobacco}

One study found a correlation between alcohol consumption and pancreatic cancer risk (10). It was performed in Finnish males with a history of alcohol abuse, and a high incidence of pancreatic cancer was reported when compared to Finland's general population overall. At least three additional studies demonstrated a poor or absent correlation between alcohol ingestion and pancreatic cancer (11-13).

Tobacco has also been associated with pancreatic cancer (14). A study of heavy smokers (at least two packs of cigarrettes a day) at the Veterans Adminitration Hospital showed that their incidence of pancreatic cancer was almost twice as high when compared to non-smokers (15). Tobacco smoke contains a number of carcinogens, including nitrosamines, shown to induce pancreatic malignancies in experimental animals (16).

\section{Pancreatitis. Diabetes}

Pancreatic carcinoma is more common in patients with chronic pancreatitis (17). Several epidemiological studies $(5,6)$ have also shown that nearly $15 \%$ of patients have a history of diabetes mellitus, which seemingly is a higherthan-expected figure. However, the onset of clinical diabetes preceded the diagnosis of pancreatic cancer by not more than 3 months in more than half of patients with diabetes and pancreatic cancer (18). This indicates that pancreas carcinoma may result in endocrine pancreatic failure. Diabetes mellitus may be a valid etiologic correlate of pancreas carcinoma when present prior the latter's development; however, such an association is uncommon (19).

\section{Genetic aspects}

The role of inheritance as a risk factor for exocrine pancreatic cancer has been examined with inconclusive results. A number of studies suggested a familiar aggregation in pancreatic cancer $(20,21)$. It is estimated that 3 to $10 \%$ of pancreatic tumors may result from genetic causes. Major hereditary cancer syndromes associated with this malignancy include hereditary non-polypoid colon cancer (HNPCC), familiar breast cancer in association with changes in BCRA2, FAMM or p16 ${ }^{\mathrm{INK4A}}$, ataxia-telangiectasia, and von Hippel-Lindau disease (22-24). Cystic fibrosis and hereditary chronic pancreatitis have also been related to an increased frequency of pancreatic cancer $(17,22)$. The potential role of metabolic enzyme genetic polymorphisms in increasing or decreasing the risk of pancreatic cancer remains unclear. Few studies on this subject exist, and their methods allow no conclusions to be drawn $(22,25,26)$.

\section{Petroleum derivatives}

Long-term exposure to solvents and petroleum components seems to be a risk factor for pancreatic cancer (18). An increased incidence was demonstrated by a prospective study in workers exposed to benzidine and beta-naphthylamine (27). Nitrosamines are known to be powerful pancreatic carcinogens in hamsters. Aza resin has also been shown to induce pancreatic tumors in rats. Continued exposure to these chemicals for 10 or more years may increase the risk of pancreas carcinoma $(18,28,29)$.

\section{PATHOLOGIC CLASSIFICATION}

Pancreatic duct adenocarcinoma is the most common neoplasm, and makes up for around $80 \%$ of all pancreatic cancers.

Invasion of the adjacent duodenum resulting in duodenal ulceration and obstruction occurs in $25 \%$ of carcinomas of the head of the pancreas.

A distinct pathologic characteristic of pancreatic adenocarcinomas is early development of metastases. At the time of diagnosis gross involvement is confined to the pancreas in $20 \%$ of patients; $40 \%$ present with locally advanced disease, including regional lymph node and adjacent tissue involvement, and almost $40 \%$ have evidence of visceral metastases upon diagnosis. Peritoneal implants are found in $35 \%$ of patients with pancreatic carcinoma.

Cystic pancreatic neoplasms are rare tumors with particular pathologic characteristics. These tumors are usually large-sized, contain mucinous secretions, and may be multilocular $(1,30)$. Microscopically, cysts are lined by a columnar epithelium (cystadenomas) or a mixture of columnar epithelium and atypical epithelial cells (cystadenocarcinomas). These carcinomas are often localized, and around 50\% may be cured with surgery alone. Other rare exocrine pancreatic tumors $(<1 \%)$ include acinar cell carcinoma, sarcoma, and lymphoma. 


\section{CLINICAL CHARACTERISTICS}

\section{Staging}

In 1981 the American Joint Committee for Cancer Staging and End Results Reporting (31) published a classification of pancreatic carcinoma based on primary tumor extension, regional lymph node involvement, and the presence of metastatic disease. The primary tumor status is defined by extension through the pancreatic capsule; nodal status is defined by regional lymph node involvement. For metastatic disease status the presence of distal lymph node, peritoneal or visceral involvement is considered. The current surgical classification is that of the TNM system, which contemplates the following stages: a) stage I: disease is confined within the pancreatic capsule and is amenable to surgical resection; b) stage II: a locally advanced tumor extending to the duodenum or peripancreatic soft tissues that may be not amenable to surgical resection; c) stage III: presence of regional lymph node involvement; and d) stage IV: presence of distant metastases.

Clinical features remain unchanged, but a number of issues should be considered:

1. Many reviews report a prolonged period of time between symptom onset and diagnosis $(32,33)$. This parameter is being questioned of late, as delays have been dramatically shortened.

2. The sudden development of diabetes mellitus as a manifestation of pancreatic failure is uncommon; however, it is thought to be a symptom of tumor progression (34).

3 . There is an increased risk of depression versus patients with other abdominal tumors (67\% for pancreatic cancer versus $10 \%$ for colon cancer) (35).

4. Patients with pancreatic carcinoma may have a higher incidence of venous thrombosis and thrombophlebitis migrans (Trousseau's sign) (36) usually in association with distal pancreatic tumors (37).

Pain is the most common symptom in patients with pancreatic cancer, and the most common reason for presentation. Virtually all patients will experience pain at some time during the course of their disease. Tipically, pain is localized to the epigastrium and right upper quadrant, and described as gnawing. On occasion it may be relieved with food, thus ressembling peptic ulcer. Pain radiation to the back develops in many patients; however, this is an uncommon presentation of pancreatic carcinoma. The presence of severe pain often reflects local or splanchnic nerve infiltration by the tumor, and is sometimes considered to predict non-resectability (37).

\section{DIAGNOSIS}

Ultrasonography may demonstrate a mass within the pancreas, dilated extrahepatic bile ducts, or metastatic disease of the liver $(38,39)$. Of late, endoscopy-guided ultrasonography represents an advance in the diagnosis of small tumors, and has proven useful in the guiding of diagnostic FNAB (40-42).

Diagnosis and disease staging rely on computerized tomography (CT). CT scans may demonstrate a mass within the pancreas, metastatic disease of the liver and both the periaortic and retropancreatic lymph nodes, and the presence of ascites. Clearly identified cystic changes, with or without calcification, suggest a cystdenoma or cystdenocarcinoma (32). Improved imaging techniques provide more accurate staging, which has an impact on preoperative decision making regarding tumor resectability $(43,44)$. One of the most common causes of non-resectability usually undetected by CT is vascular infiltration; the sensitivity of helical CT for accurately assessing vascular infiltration is around 60-89\% $(45,46)$. Modern CT imaging $(20,47,48)$ facilitates the diagnosis of small tumors and of their anatomical relations to vasculature, thus providing more accurate preoperative staging; it even allows virtual Wirsungraphy (48).

Endoscopic retrograde cholangio-pancreatography (ERCP) continues to be a valuable diagnostic tool for ampullary tumors, as well as for the identification of sclerosed or obstructed bile and pancreatic ducts.

Seemingly localized tumors should prompt an assessment of resectability. Again CT plays a relevant role in decision making, particularly upon assessing upper mesenteric vessels and the celiac trunk. If these structures are not involved, a CT-based assessment of portal obstruction may be performed, and resection may be considered.

Angiography is used to establish the presence of abnormal vascularization, such as a right hepatic artery branching off the upper mesenteric artery, as well as to determine nonresectability based on the infiltration of the upper mesenteric artery or, more rarely, hepatic arteries or celiac trunk. When CT scans demonstrate a complete infiltration of the upper mesenteric arteries or celiac trunk resection is formally contraindicated. Angio-CT has currently replaced conventional angiography.

Histologic confirmation using pancreatic fine-needle aspiration or a percutaneous biopsy of liver metastases is required for non-resectable tumors or when metastatic disease is identified (49). The sensitivity of cytology may be increased by genetic studies in search of K-ras gene mutations (21).

Contrast-enhanced upper gastrointestinal radiography is much less valuable than CT and usually unnecessary, since most patients will undergo endoscopy during ERCP. Magnetic resonance imaging (RMI) provides no significant findings in the pancreatic area. MRI may eventually replace CT over time, but the latter is currently the procedure of choice.

Laparoscopy has been recently introduced as a diagnostic and staging technique potentially allowing palliative therapy $(44,50)$.

\section{TUMOR MARKERS}

Serum markers of pancreatic cancer are highly beneficial for a number of reasons. Some are sensitive and specific enough to help in the differential diagnosis of patients with retroperitoneal and abdominal disease. They may also identify patients with resectable, curable disease with greater ease. Their usefulness for patient follow-up must be born in mind as well. 


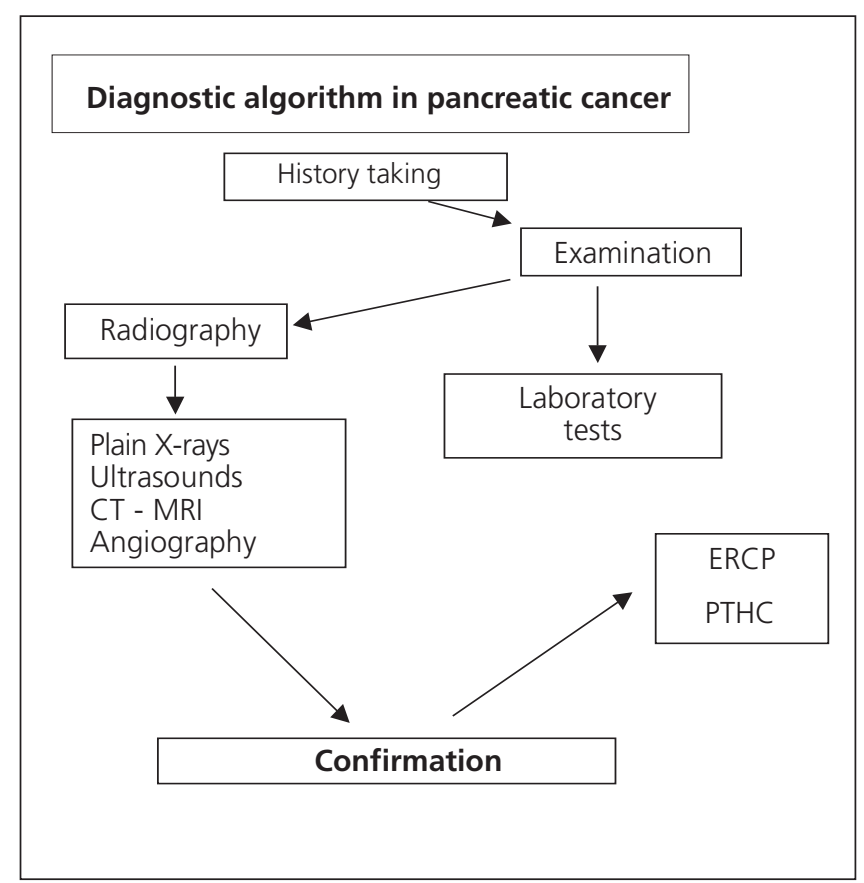

Fig. 1.

One of the first systematically investigated markers is carcinoembrionary antigen (CEA). This test identifies nearly half of patients with pancreatic cancer, and may tell pancreatic malignancies from benign conditions in more than $90 \%$ of patients. However, CEA is not a valid marker for diagnosis or follow-up $(51,52)$.

CA-125 antigen is a marker of ovarian epithelial malignancies that has been studied with regard to other gastrointestinal tract tumors (53-55). In patients with pancreatic carcinoma, CA-125 is detected in fewer than $50 \%$ of cases. CA-125 is unsatisfactory as a single test for pancreatic carcinoma, and is likely more useful in ovarian cancer.

Carbohydrated antigen (CA-19.9) has been associated with both pancreatic neoplasms and other abdominal malignancies. Results from five significant trials are fully consistent (56-60). Approximately $80 \%$ of patients with pancreatic cancer may be correctly diagnosed using this monoclonal antibody, versus $8 \%$ of patients with pancreatitis and $1 \%$ of incorrectly identified healthy subjects. Steinberg reported thatl CA-19.9 was statistically more specific than CEA (86.5 versus $48.4 \%$ ) but only slightly more sensitive than CEA (92.5 versus $87.3 \%$ ) (56). Data reported by Piantino showed identical superiority for CA-19.9 (57). Tempero suggested that CA-19.9 may be a useful clinical marker to detect pancreatic cancer progression in patients with either recurrent or advanced disease (61).

More recently, an additional monoclonal antibody designated DU-PAN-2, a seemingly oncofetal surface antigen, has proven strongly specific for pancreatic cancer identification and follow-up (62). DU-PAN-2 may be elevated in patients with biliary cirrhosis, gastric cancer, and biliary cancer; it seems to be sensitive and specific enough for pancreatic cancer, and thus deserves further assessment.
The concurrent use of several markers (CA-19.9 and CA-125) may lead to a clearer differentiation between various diseases as well as to optimal clinical outcomes. In this sense increased plasma levels of TFPI (tissue factor pathway inhibitor) have been reported (63). Regenerating proteins, the expression of the reg gene, are useful markers of acinar cell differentiation (64). Other monoclonal antimucin (CMA-17/WGA) (65) and antimurin (HAMA) (66) antibodies are used for serologic diagnosis, and their sensitivity and specificity increase in association with CA-19-9.

Pyruvate kinase isoenzyme $\mathrm{K}(\mathrm{PK}-\mathrm{K})$ is considered a marker of pancreatic cancer progression (67). CA-242 and lectins BPA and VVA are poorly sensitive but highly specific regarding diagnosis $(68,69)$.

\section{REFERENCES}

1. De Diego IA. Tumores del páncreas exocrino. En: Balibrea Cantero JL, ed. Tratado de Cirugía. Tomo II. Barcelona: Ediciones Toray S.A., 1989. p. 2578-87.

2. Moossa AR. Tumours of the pancreas. In: Moossa AR, Schimpf SC, Rabson MC. Comprehensive textbook of oncology. Volumen I. Second ed. Williams and Wilkins, 1991. p. 958-88.

3. Mori K, Ikei S, Yamane T, Yamaguchi Y, Katsumori T, Shiabta Y, Arai T. Pathological factors influencing survival of carcinoma of the ampulla of vater. Europ J Surg On 1990; 16; 183-7.

4. Schwartz S. Cirugía de páncreas. En: Schwartz, Shires y Spencer, eds. Principios de Cirugía. Interamericana, 1991.

5. Hoover R, Mason T, Mckay F, et al. Geographic patterns of cancer mortality in the United States. In: Fraumeni JF, ed. Persons at High Risk of Cancer. An Approach to Cancer Etiology and Control. New York: Academic Press, 1975. p. 343-60.

6. Appel MJ, Meijers M, Van Garderen-Hoetner A, Lamers CB, et al. Role of cholecystectokinin in dietary fat-promotedaserine induced pancreatic carcinogenesis in rats. Br J Cancer 1992; 66: 46-50.

7. Mac Mahon B, Yen S, Trichopoulos D, et al. Coffee and cancer of the pancreas. N Engl J Med 1981; 304: 630.

8. Feinsten A, Horowitz R, Spitzer W, et al. Coffee and pancreatic cancer: the problems of etiologic science and epidemiologic case-control research. JAMA 1981; 246: 957.

9. Howe GR, Burch JD. Nutrition and pancreatic cancer. Cancer Causes Control 1996; 7: 69-82.

10. Hakulinen T, Lehtimaki L, Lehtonen $\mathrm{M}$, et al. Cancer morbidity among two male cohorts with increased alcohol consumption in Finland. J Natl Cancer Inst 1974; 52: 1711.

11. Wynder E, Mabuchi K, Maruchi N, et al. A case control study of cancer of the pancreas. Cancer 1973; 31: 641.

12. Wynder E, Mabuchi K, Maruchi N, et al. Epidemiology of cancer of the pancreas. J Natl Cancer Inst 1973; 50: 645.

13. Monson R, Lyon J. Proportional mortality among alcoholics. Cancer 1975; 36: 1077.

14. Newcomb PA, Carbone PP. The health consequences of smoking. Med Clin North 1991; 6: 305-31.

15. Kahn H. The Dorn study of smoking and mortality among US veterans: report on eight and one-half years observation. Natl Cancer Inst Monogr 1966; 19: 1.

16. Sindelar W, Kurman C. Nitrosamine-induced pancreatic carcinogenesis in outbred and inbred Syrian hamsters. Carcinogenesis 1982; 3: 1021.

17. Beger HC, Büchler M, eds. Chronic pancreatitis. Research and clinical management. Springer Verlag, 1990.

18. Brooks J. Cancer of the pancreas. In: Brooks JR, ed. Surgery of the pancreas. Philadelphia: WB Saunders, 1983. p. 263.

19. Sasaki A, Kamado K, Horiuchi N. A changing pattern of causes of death in japanese diabetics. Observations over fifteen years. J Chronic Dis 1978; 312: 433 . 
20. Ghadirian P, Boyle P, Simard A. Reported family aggregation of pancreatic cancer within population-based-case-control study. Pancreas 1991; 10: 183-96.

21. Fernández E, La Vecchia C, Decarli A. Attributable risk for pancreatic cancer in northern Italy. Cancer Epidemiol. Biomarkers 1996; 5: 23-7.

22. Anderson KE, Potter JD, Mack TM. Pancreatic cancer. En: Schottenfeld D, Fraumeni FJ, eds. Cancer epidemiology and prevention. $2^{\mathrm{a}}$ ed. Nueva York: Oxford University Press, 1996. p. 725-71.

23. Swift M, Morrell D, Massey RB, Chase CL. Incidence of cancer in 161 families affected by ataxia-telangiectasia. N Engl J Med 1991; 325: $1831-6$

24. Ozcelik H, Schmocker B, Di Nicola N, Shi XH, Langer B, Moore M, et al. Germline BRCA2 6174delT mutations in Ashkenazi Jewish pancreatic cancer patients. Nat Genet 1997; 16: 17-8.

25. Braganza JM. Pancreatic disease: a casualty of hepatic "detoxification"? Lancet 1983; 29: 1000-3.

26. Collier JD, Bennett MK, Hall A, Cattan AR, Lendrum R, Bassendine MF. Expression of glutathione S-transferases in normal and malignant pancreas: an inmunohistochemical study. Gut 1994; 35: 266-9.

27. Mancuso T, El-Attar A. Cohort study of workers exposed to betanaphythylamine and benzidine. J Occup Med 1967; 9: 277.

28. Pour P, Althoff J, Kruger F, et al. The effect of N-Nitrosobis (2-oxopropyl)almine after administration to hamsters. Cancer Lett 1977; 2 : 323.

29. Longnecker D, Curphey T. Adenocarcinoma of the pancreas in azaserine-treated rats. Cancer Res 1975; 35: 2249.

30. Duran H. Quistes y pseudoquistes. En: Durán Sacristán H, Arcelus I, García-Sancho L, González F, Álvarez J, Fernández L, Méndez J, eds. Tratado de Patología y Clínica Quirúrgicas. Madrid: Interamericana McGraw-Hill, 1992. p. 2818-53.

31. Cancer of the pancreas Task force: Staging of cancer of the pancreas. Cancer 1981; 47: 1631.

32. Gudjonsson B. Livestone EM. Spiro HM. Cancer of the pancreas. Diagnostic accuracy and survival statistics. Cancer 1978; 42: 2494.

33. Howard JM, Jordan GL. Cancer of the pancreas. Curr Probl Cancer 1977; $2: 1$.

34. Go VLW, Taylor WF, DiMagno EP. Efforts and early diagnosis of pancreatic cancer: The Mayo Clinic experience. Cancer 1981; 47: 1698.

35. Fras I, Litin EM, Pearson JS. Comparison of psychiatric symptoms in carcinoma of the pancreas with those in some other intra-abdominal neoplasms. Am J Psychiatry 1967; 123: 1553.

36. Sack GH, Levin J, Bell WR. Trousseau's syndrome and other manifestations of chronic disseminated coagulapathy in patients with neoplasms: clinical, pathophysiologic and therapeutic features. Medicine 1977; 56: 1 .

37. Moertel CG. Exocrine pancreas. In: Holland JF, Frei E, eds. Cancer Medicine. 2nd ed. Philadelphia: Lea \& Febiger, 1982. p. 1792-804.

38. Bengmark S. Progress in surgery of the liver and biliary system. Martinua Nijhoff Publish, 1988.

39. Moossa AR. Diagnosis and treatment of "early" pancreatic cancer. In: Williams LF, Sawyer JL, eds. Difficult problems in general surgery. Chicago: Year Book Medical Publishers, 1989. p. 285-98.

40. Rösch T, Lorenz R, Braig C, Fenerbach S, Siewert JR, Schusdziarra $\mathrm{V}$, et al. Endoscopic Ultrasound in pancreatic Tumor diagnosis. Gastrointestinal 1991; 37: 347-52.

41. Legman P, Viguanse O, Dourset B, et al. Pancreatic tumors: comparison of dual-phase helical and endoscopic soundography. Anna J Radial 1998; 170: 1315-22

42. Faisel DO, Ginsbrg GG, Bentz IS, Gupta PK, Smith DB, Kochman ML. Endoscopic ultrasound-gided realtime fine needle aspiration biopsy of the pancreas in cancer patients with pancreatic lesions. J Clin Oncol 1997; 15: 1439-43.

43. Catalano C, Laghi A, Fraioli F, Napoli A, Danti M, Reitano I, et al. Pancreatic carcinoma: the role of high-resolution miltislice spiral CT in the diagnosisis and assessment of respectability. Eur Radiol 2002; 13: $149-56$.

44. Yoshida T, Matsumoto T, Morii Y, Ishio T, Kitano S, Yamada Y, et al. Staging with helicol computed tomography and laparoscopy in pancreatic head cancer. Hepatogastroenterology 2002; 49: $1428-31$

45. Zeman RK, Cooper, Zeiberg AS, et al. TNM Stafing of pancreatic carcinoma using hecal CT. AJR J Rosentsenol 1997; 169: 459-64.

46. Diehl SJ, Lehmann KJ, Sadick M, Lachmann R, Georgi M. Pancreatic cancer value of dual-phase helical CT assessing respectability. Radiology 1998; 206: 373-8.

47. Prokech RW, Chow LC, Beaulieu Ch F, Nino-Murcia M, Mindelzun RE, Bamer R, et al. Local staging of pancreatic carcinoma with multidetector row CT: Use of curve planar reformations. Initial experience. Radiology 2002; 225: 759-65.

48. Tanizawa Y, Nakagohri T, Konoshi M, Inoue K, Oda T, Takahashi S, et al. Virtual pancreatoscopy of pancreatic cancer. Hepato-gastroenterology 2003; 50: 559-62.

49. Wilson MB, Adams DB, Garen PD, Gansler TS. Aspiration cytologic, ultrastructural and DNA cytometric findings of solid and papillary tumour of the pancreas. Cancer 1992; 69: 2235-43.

50. Nieveen van Dijkum EJ, Romijn MG, Terwee CB, de Wit LT, van der Meulen JH, Lameris HS, et al. Laparoscopic staging and subsequent palliation in patients with peripancreatic carcinoma. Ann Surg 2003; 237: 66-73.

51. Moosa AR, Levin B. The diagnosis of "early" pancreatic cancer. The University of Chicago experience. Cancer 1981; 47: 1688.

52. Holyoke ED, Evans JT, Mittleman A. Biochemical markers for cancer. New York: Marcel Dekker, 1982. p. 61-80.

53. Van Nagell Jr. Tumour markers in ovarian cancer. Clin Obstet Gynecol 1983; 10: 197.

54. Pentti K, Keinonen KT, Koiwla T, et al. Tumour associated antigen CA 12-5 in patients with ovarian cancer. Br J Obstet Gyneacol 1985; 92: 528 .

55. Bast RC, Klug TL, St. John E, et al. A radioimmunoassay using a monoclonal antibody to monitor the course of epithelial ovarian cancer. N Engl J Med 1983; 309: 883.

56. Steinberg WM, Gelfand R, Anderson KK, et al. Comparison of the sensivity and specificity of the CA 19-9 and carcinoembryonic antigen assays in detecting cancer of the pancreas. Gastroenterology 1986; 90: 343.

57. Piantino P, Andriulli A, Gindro T, et al. CA 19-9 assay in differential diagnosis of pancreatic carcinoma from inflammatory pancreatic diseases. Am J Gastroenterol 1986; 81: 436

58. Haglund C, Roberts PJ, Kuusela P, et al. Gatsroeintestinal cancer associated antigen CA 19-9 in histological specimens of pancreatic tumours and pancreattits. Br J Cancer 1986; 53: 189

59. Pasquali C, Sperti C, D'Andrea AA, et al. Evaluation of carbohydrate antigens 19-9 and 12-5 in patients with pancreatic cancer. Pancreas 1987; $2: 34$.

60. Sakahara H, Endo K, Nakajima K, et al. Serum CA 19-9 concentrations and computed tomography findings in patients in patients with pancreatic carcinoma. Cancer 1986; 57: 1324.

61. Tempero M, Uchida E, Takasaki H, et al. Serial CA 19-9 levels and tumour response in pancreatic cancer (abstr.). Proc Am Soc Clin Oncol 1987; 6: 81 .

62. Scholm J, Weeks MO. Potential clinical utility of monoclonal antibodies in the management of human carcinomas. In: Devita UT Jr, Rosenberg SA, eds. Important advances in oncology. Philadelphia: J.B. Lippincott, 1985. p. 170.

63. Lindahl AK, Odegaard OR, Sandset PM, et al. Coagulation inhibition and activation in pancreatic cancer. Cancer 1992; 70: 2067-72.

64. Kimura N, Yonekura H, Okamoto MD, et al. Expression of human regenerating gene in RNA and its product in normal and pancreatic human pancreas. Cancer 1992; 70: 1857-63.

65. Parker N, Makin CA, Ching CK, at al. A new enzyme linked lectin/mucin antibody sandwich assay (CAM 17,1/WGA). Cancer 1992; 70: 1062-8

66. Hosono M, Eudo K, Sakahara H, et al. Human mouse chimeric antobodies show low reactivity with human antimurine antibodies (HAMA). Br J Cancer 1992; 65: 197-200.

67. Van Erp H, Van Vunik J, Rijsen G, et al. Cellular expression of Ktype pyruvate kinase in normal and neoplastic human tissues. Cancer 1992; 68: 2595-600.

68. Pasamen PA, Eskelimen M, Pastamen K, et al. Clinical evaluation of a new serum tumour marker CA 242 in pancreatic carcinoma. Br J Cancer 1992; 65: 731-4.

69. Kawa S, Kato M, Hsue L, et al. Clinical evaluation of pancreatic cancer associated mucin expressing CA 19-9, CA 50, sialy SSEA-1 an Dupan 2. Scand J Gastroenterol 1992; 27: 635-43. 


\title{
Cáncer de páncreas. Epidemiología y diagnóstico
}

\author{
M. Hidalgo Pascual, E. Ferrero Herrero, M. J. Castillo Fé. F. J. Guadarrama González, P. Peláez Torres y F. Botella \\ Ballesteros
}

Servicio de Cirugía General y Digestivo "B". Hospital Universitario 12 de Octubre. Madrid

\section{INTRODUCCIÓN}

El cáncer de páncreas ocupa el cuarto lugar en la mortalidad por cáncer en Estados Unidos. La frecuencia de nuevos casos de esta enfermedad y la tasa de fallecimientos cada año están muy próximas. En 1988 aproximadamente 27.000 nuevos casos fueron vistos en Estados Unidos, de los cuales cerca de 24.500 fallecieron; en 1999, se registraron 185.000 nuevos casos, con una frecuencia de fallecimientos: incidencia del 0,99, falleciendo 28.000 pacientes en EE.UU. por esta enfermedad (en 1998), lo cual da una idea del incremento anual del cáncer de páncreas. En España, las cifras señalan una mortalidad en los últimos 40 años que ha aumentado un $164 \%$ en las mujeres y un $200 \%$ en los varones. Más concretamente, en el área de referencia de nuestro hospital han sido diagnosticados 58 nuevos casos de cáncer de páncreas al año (8,3\% respecto al total de tumores del aparato digestivo). La frecuencia de esta enfermedad únicamente se encuentra superada por el cáncer de pulmón, colon y recto, próstata y mama (1-4).

\section{CONSIDERACIONES EPIDEMIOLÓGICAS}

\section{Incidencia}

La mortalidad puede ser un buen indicador de la frecuencia, debido a que la mayoría de los pacientes con cáncer de páncreas mueren por esta enfermedad, dado que la precisión del diagnóstico es alta. La fiabilidad puede ser comprobada comparando el número de casos histológicamente confirmados mediante intervención, biopsia y autopsia con el número de casos diagnosticados. Esta cifra oscila entre el 75 y el $95 \%$.

\section{Edad y sexo}

El cáncer de páncreas está aumentando paulatinamente y la proporción diagnóstico-fallecimiento, se incrementa con la edad. La edad media en informes nacionales en EE.UU. desde 1973 hasta 1977 es de 69,2 años para hombres y 69,5 años para mujeres. La proporción hombre-mujer es distinta según la edad, como ha sido relatado en diferentes publicaciones. Los fallecimientos por cáncer varían de 2:1 en pacientes mas jóvenes de 40 años a 1:1 en pacientes mayores de 80. Los datos actuales indican que la proporción hombremujer según la edad son los siguientes, mas jóvenes de 40 años son $3: 1 ; 1,8: 1$ desde 41 a 50 años; $1,2: 1$ entre 51 y 80 años; y 1,1:1 para pacientes mayores de 80 años.

\section{Aspectos demográficos}

En Israel ha sido examinada la influencia del lugar de nacimiento y la extensión del cáncer de páncreas varía de 10,4 por 100.000 hombres nacidos en Europa o América a 5,6 por 100.000 hombres nacidos en Israel.

Fluctuaciones similares pueden ser demostradas en la incidencia en mujeres en determinados sitios de diferentes países. Por ejemplo la frecuencia varía de 11 por 100.000 en Ontario (Canadá), a 3,7 en el territorio noroeste de Canadá. En Inglaterra y Gales desde 1911 a 1971, la mortalidad por cáncer de páncreas tanto en hombres como en mujeres ha aumentado cuando menos cinco veces.

La frecuencia del cáncer de páncreas, es diferente para comunidades o grupos étnicos diversos, así las poblaciones hispanas en Los Ángeles (EE.UU.) da cifras del 11,7 por 100.000 habitantes frente al 2 por 100.000 que presenta la comunidad china en esa misma ciudad. En Europa las cifras son asimismo llamativas: en Francia la proporción anual es de 6 nuevos casos por cada 100.000 hombres y 3 casos por cada 100.000 mujeres. En Italia cada año hay 10 nuevos casos por 100.000 habitantes. En España la incidencia se encuentra alrededor de 7/100.000.

\section{ETIOLOGÍA}

Diversos factores ambientales han sido relacionados, con un elevado riesgo del cáncer de páncreas, aunque la causa exacta continúa poco clara. El cáncer pancreático, como otras neoplasias comunes, parece ser más frecuente entre personas de grupos socioeconómicos más bajos (5).

\section{Hábitos dietéticos}

Han sido implicados así mismo diversos factores dietéticos (6). Al menos un estudio demostró, una correlación real entre el consumo de café y el cáncer de páncreas. En este estudio (7), fueron hallados pacientes con cáncer de páncreas con un historial de mayor consumo de café que el grupo de control de pacientes con desarreglos gastrointestinales benignos. Se han 
hecho al menos otros dos estudios, que no han confirmado la asociación entre consumo de café y cáncer de páncreas (8).

Howe y Burch (9), en las conclusiones de un estudio multicéntrico para valorar micronutrientes y cáncer de páncreas, destacan el aumento de riesgo asociado a la ingesta de hidratos de carbono y colesterol y el descenso asociado al consumo de fibra y vitamina $\mathrm{C}$.

\section{Alcohol y tabaco}

Un estudio indicó una conexión entre el consumo de alcohol y el riesgo de padecer cáncer de páncreas (10). Fue realizado en hombres finlandeses, con historia de abuso de alcohol, apareciendo una alta incidencia de cáncer de páncreas, comparado con el global de la población finlandesa. Al menos otros tres estudios han demostrado una pequeña o nula correlación entre el consumo de alcohol y el cáncer de páncreas (11-13).

El tabaco ha sido también asociado al cáncer de páncreas (14). Un estudio del Hospital de la Administración de Veteranos, de las personas muy fumadoras (al menos 2 paquetes por día) demostró (15), casi el doble de incidencia de cáncer pancreático, comparado con los no fumadores. El humo del tabaco contiene carcinógenos, incluyendo nitrosaminas que han producido neoplasias pancreáticas en animales de laboratorio (16).

\section{Pancreatitis. Diabetes}

El carcinoma pancreático se encuentra con mayor frecuencia en pacientes afectos de pancreatitis crónica (17). Varios estudios epidemiológicos $(5,6)$ han demostrado también que casi un $15 \%$ tiene historia de diabetes mellitus, lo cual parece ser una cifra más alta de lo esperado. Sin embargo, en más de la mitad de pacientes con diabetes y cáncer de páncreas, el comienzo de la diabetes clínica precedió al diagnóstico de carcinoma pancreático en no más de 3 meses (18). Esto nos indica que el carcinoma puede producir insuficiencia endocrina de páncreas. La diabetes mellitus, cuando existe antes del desarrollo del cáncer de páncreas, podría ser una prueba muy valida para una correlación etiológica, pero este tipo de relación no se encuentra con frecuencia (34).

\section{Aspectos genéticos}

Se ha estudiado el papel de la herencia como factor de riesgo del cáncer de páncreas exocrino, aunque sin resultados concluyentes. Algunos estudios han señalado la agregación familiar de cáncer de páncreas (20,21). Se estima que entre el 3 y el $10 \%$ de tumores pancreáticos podrían ser debidos a causas genéticas. Los principales síndromes de cáncer hereditario asociados a este tumor son el cáncer de colon hereditario no polipoideo (HNPCC), el cáncer de mama familiar asociado a alteraciones en BCRA2, el FAMM, el asociado a alteraciones en $\mathrm{p} 16^{\mathrm{INK} 4 \mathrm{~A}}$, la ataxia telangiectasia y el de Von Hippel-Lindau (22-24). La fibrosis quística y la pancreatitis crónica hereditaria han sido también asociadas a una mayor frecuencia de cáncer de páncreas $(17,22)$. El papel que puedan tener los polimorfos genéticos de enzimas metabolizadoras, aumentando o disminuyendo el riesgo de cáncer de páncreas, no está aún claro. Existen pocos estudios al respecto y la metodología empleada en ellos no permite establecer conclusiones $(22,25,26)$.

\section{Derivados del petróleo}

Exposiciones a largo plazo a disolventes y componentes del petróleo parecen ser factores de riesgo (18). En un estudio prospectivo de trabajadores expuestos a benzidina $\mathrm{y}$ beta-naftilamina se demostró una mayor incidencia (27). Las nitrosaminas son conocidas como potentes carcinogenéticos pancreáticos en hámsters. También se ha demostrado que la azaresina produce tumores pancreáticos en las ratas. El contacto continuado durante 10 años o más a estos productos químicos puede incrementar el riesgo a padecer carcinoma pancreático $(18,28,29)$.

\section{CLASIFICACIÓN PATOLÓGICA}

La neoplasia más común, es el adenocarcinoma del conducto pancreático, el cual representa alrededor del $80 \%$ de todos los cánceres de páncreas.

La invasión del duodeno contiguo, con ulceración y obstrucción del duodeno, sucede en el $25 \%$ de los carcinomas de cabeza de páncreas.

Una característica patológica distintiva de los adenocarcinomas pancreáticos es el desarrollo precoz de metástasis. El $20 \%$ de los pacientes tiene enfermedad macroscópicamente limitada al páncreas en el momento del diagnóstico: $40 \%$ se presentan con enfermedad avanzada local, incluyen compromiso de los nódulos regionales linfáticos y tejidos contiguos pancreáticos, y cerca del $40 \%$ tienen evidentes metástasis viscerales, cuando se diagnostica el cuadro. Los implantes peritoneales se encuentran en el 35\% de los pacientes afectos de carcinoma pancreático.

Las neoplasias quísticas del páncreas son tumores raros que tienen características patológicas especiales. Estos tumores son normalmente grandes, llenos de secreciones mucinosas y pueden ser multiloculares $(1,30)$. Microscópicamente, los quistes están formados por una columna epitelial cistoadenomas o con una mezcla de columna epitelial y células epiteliales con atipias (cistoadenocarcinomas). Estos carcinomas, a menudo son localizados, y aproximadamente el $50 \%$ de ellos pueden ser curados solo con cirugía. Otros tumores $(<1 \%)$ raros del páncreas exocrino incluyen carcinomas de células acinares, sarcomas y linfomas.

\section{CARACTERÍSTICAS CLÍNICAS}

\section{Grados de extensión}

En 1981 el American Joint Committee for Cancer Staging and End Results Reporting (31) publicó una clasifica- 
ción del carcinoma pancreático basada en el alcance del tumor primario, la condición de los nódulos regionales linfáticos, y la presencia de enfermedad metastásica. El tumor primario viene definido por la extensión a través de la cápsula pancreática; los nódulos fueron definidos por colonización o no de los linfáticos regionales y para el estado de enfermedad metastásica se consideró la presencia de nódulo distal linfático, peritoneal o enfermedad visceral metastásica. La clasificación quirúrgica actual es la del sistema TNM que considera los siguientes estadios: a) estadio I: la enfermedad es localizada dentro de la cápsula pancreática y susceptible de resección quirúrgica; b) estadio II: tumor localmente avanzado con invasión de duodeno o tejidos blandos peripancreáticos y que puede no ser resecable quirúrgicamente; c) estadio III: existen nódulos linfáticos regionales colonizados; y d) estadio IV: existen metástasis a distancia.

Las características clínicas no se han modificado, si bien hay aspectos que deben ser tenidos en cuenta:

1. Múltiples trabajos exponen el dilatado espacio de tiempo que transcurre entre el comienzo de los síntomas y el diagnóstico $(32,33)$. Este parámetro comienza a ser cuestionado, dado que se esta acortando extraordinariamente ese espacio.

2. La repentina aparición de diabetes mellitus como una manifestación de insuficiencia pancreática es poco habitual, si bien se cree que es un síntoma del desarrollo del tumor (34).

3. Existe un mayor riesgo de depresión en estos pacientes, comparados con enfermos con otros tumores abdominales $(67 \%$ en cáncer pancreático frente al $10 \%$ en cáncer de colon) (35).

4. Los pacientes con carcinoma pancreático pueden tener mayor frecuencia de trombosis venosa y tromboflebitis migratoria (signo de Trousseau) (36) y se relaciona generalmente con tumores del páncreas distal (37).

El dolor es el síntoma más común en pacientes con carcinoma pancreático y es la razón por la que se produce la consulta médica. Prácticamente todos los pacientes tendrán dolor en algún momento de su enfermedad. Típicamente, el dolor se localiza en el epigastrio o hipocondrio derecho y es descrito como punzante. Ocasionalmente, puede ser mitigado con comidas, imitando la enfermedad de úlcera péptica. La irradiación del dolor a la espalda aparece en muchos pacientes, pero, sin embargo, es una presentación poco común del carcinoma pancreático. La presencia de dolor intenso es a menudo indicativo de infiltración local o de los nervios esplácnicos y, a veces, es considerado como un signo de irresecabilidad (33).

\section{DIAGNÓSTICO}

Una ecografía puede demostrar una masa en el páncreas, conductos biliares extrahepáticos dilatados o enfermedad metastásica en el hígado $(38,39)$. Recientemente la ecografía guiada por endoscopia ha supuesto un avance en el diagnóstico de pequeños tumores y ha sido útil para guiar la PAAF diagnóstica (40-42).

La tomografía axial computarizada (TAC) es la base de diagnóstico, y la evaluación de la extensión de la enferme- dad. La TAC puede demostrar la masa en el páncreas, enfermedad metastásica en el hígado y los nódulos linfáticos periaórticos y retropancreáticos, así como la presencia de ascitis. Una clara identificación de cambios quísticos, con o sin calcificación, indican la posibilidad de cistodenoma o cistodenocarcinoma (32). La mejoría en las técnicas de imagen posibilita un diagnóstico de extensión más exacto con implicaciones sobre la posibilidad de toma de decisiones preoperatorias en relación con la resecabilidad del tumor $(43,44)$. Una de las causas más frecuentes de irresecabilidad no detectada por TAC es la infiltración vascular por el tumor; la sensibilidad de la TAC helicoidal para valorar correctamente dicha infiltración vascular es alrededor del 60-89\% $(45,46)$. Las modernas metodologías de imagen por TAC $(20,47,48)$ facilitan el diagnóstico de tumores pequeños y su relación anatómica con el árbol vascular, haciendo más correcto el estadiaje preoperatorio, siendo incluso posible la realización de una wirsungrafía virtual por estos métodos (48).

La colangiopancreatografía retrógrada endoscópica (CPRE), sigue siendo un valioso instrumento en el diagnóstico de los tumores de ampolla y para la identificación de los conductos biliares y pancreáticos esclerosados y obstruidos.

Si el tumor parece localizado, el siguiente paso es evaluar su resecabilidad. Otra vez la TAC representa un papel importante en la decisión, especialmente valorando los vasos mesentéricos superiores y tronco celiaco. Si estos no están implicados puede realizarse una valoración de la obstrucción de la vena porta en base a la TAC, y ser tomada en cuenta la resección.

La angiografía es utilizada por un lado para determinar la presencia de vascularización anormal, como una arteria hepática derecha rama de la arteria mesentérica superior, y por otro lado para determinar la irresecabilidad basada en la infiltración de la arteria mesentérica superior, o más raramente, arterias hepáticas o tronco celiaco. Cuando en la TAC se demuestra la completa infiltración de las arterias mesentérico superior o tronco celiaco, la resección está formalmente contraindicada. El angioTAC ha sustituido actualmente a la angiografía tradicional.

En los tumores irresecables, o cuando se identifica enfermedad metastásica, se debe conseguir la confirmación histológica por medio de punción aspiración con aguja fina (PAAF) del páncreas o de biopsia percutánea de la metástasis del hígado (49). La sensibilidad de la citología puede aumentarse con el estudio genético buscando mutaciones del gen K-ras (21).

Estudios radiológicos de contraste del tramo gastrointestinal superior son mucho menos valiosos que la TAC, y a veces son innecesarios teniendo en cuenta que gran número de los pacientes tendrán una endoscopia como parte de la CPRE. La resonancia magnética nuclear (RMN) no aporta evaluaciones importantes en el área pancreática. La RMN puede, con el tiempo, sustituir a la TAC, pero actualmente esta última es el procedimiento de elección.

Recientemente se ha introducido la laparoscopia como método de diagnóstico y estadiaje con posibilidades de tratamiento paliativo $(44,50)$. 


\section{MARCADORES TUMORALES}

Los marcadores serológicos del carcinoma de páncreas aportan grandes beneficios por múltiples razones. Algunos son suficientemente sensibles y específicos y ayudan a realizar el diagnóstico diferencial de pacientes con enfermedad retroperitoneal y abdominal. Pueden también identificar más fácilmente los pacientes con enfermedad resecable y curable. Así mismo, es preciso recordar su utilidad para el seguimiento clínico de los pacientes.

Uno de los primeros investigado metódicamente fue el antígeno carcinoembrionario (CEA). Esta prueba identifica alrededor de la mitad de los pacientes con cáncer pancreático y puede discriminar las enfermedades pancreáticas malignas de las benignas en más del 90\% de los casos. Sin embargo, el CEA no es un marcador válido para diagnóstico o seguimiento $(51,52)$.

El antígeno CA 125 es un marcador para neoplasias de epitelio ovárico y ha sido sometido también a investigación en otras del tracto gastrointestinal (53-55). En pacientes con carcinoma pancreático, el CA 125 es detectado en menos del $50 \%$ de los casos. Como examen único en carcinoma pancreático, el CA 125 no es satisfactorio clínicamente, siendo probablemente mas útil en cáncer de ovario.

El antígeno carbohidratado (CA 19.9) ha sido relacionado tanto con neoplasias pancreáticas como con otras de localización abdominal. Los resultados obtenidos en cinco estudios representativos están perfectamente concretados (56-60). Con este anticuerpo monoclonal aproximadamente el $80 \%$ de pacientes con cáncer pancreático se diagnostican correctamente, comparados con el $8 \%$ de los pacientes con pancreatitis y el $1 \%$ de sujetos normales identificados incorrectamente, Steinberg descubrió que el CA 19.9 era estadísticamente más específico que el CEA $(86,5$ contra el $48,4 \%)$ pero sólo ligeramente más sensible $(92,5$ contra 87,3\%) (56). Datos citados por Piantino demostraron una idéntica superioridad para el CA 19.9 (57). Tempero sugiere que el CA 19.9 puede ser un útil marcador clínico para detectar la progresión del cáncer pancreático en pacientes con enfermedad recurrente o avanzada (61).

Más recientemente, otro anticuerpo monoclonal denominado DU-PAN-2, parece ser un antígeno oncofetal de superficie que es muy específico para identificar y seguir el cáncer pancreático (62). El DU-PAN-2 puede estar elevado en pacientes con cirrosis biliar, cáncer gástrico, y cáncer biliar pero parece ser sensible y específico para el cáncer pancreático y merece una evaluación adicional.

El uso simultáneo de varios de ellos (CA 19.9 y CA 125) puede conducir a una más clara distinción entre diferentes enfermedades y resultados clínicos óptimos. En este sentido se ha demostrado un incremento de los niveles plasmáticos de TFPI (factor insular inhibidor de coagulación) (63). Las proteínas regenerantes, expresión del gen reg, son un marcador útil para la diferenciación celular acinar (64). Otros anticuerpos monoclonales antimucina (CMA 17/WGA) (65) y antimurinos (HAMA) (66) se utilizan para el diagnóstico serológico, aumentando su sensibilidad y especificidad en asociación con el CA 19-9.

$\mathrm{La}$ isoenzima $\mathrm{K}$ de la piruvatokinasa $(\mathrm{PK}-\mathrm{K})$ se considera como un marcador de desarrollo oncológico en el cáncer de páncreas (67). El CA 242 y las lecitinas BPA y VVA presentan baja sensibilidad diagnóstica y una alta especificidad $(68,69)$. 